$\xi=-1$

\title{
Information Quality Management in the Malaysian Public Sec- tor: A Preliminary Study on Issues and Challenges
}

\author{
Erizamsha Hassan*, Zawiyah M. Yusof, Kamsuriah Ahmad \\ Faculty of Information Science and Technology, Universiti Kebangsaan Malaysia, 43600 Bangi, Selangor, Malaysia \\ *Corresponding author E-mail: erizamsha.hassan@gmail.com
}

\begin{abstract}
Information plays a significant role in enhancing an organization's capital, namely as its crucial source of income and a valuable leverage in times of unfavorable economic climate. The strategic management of information, thus, is imperative as it contributes in bringing about success to business by influencing decision-making of the organization for better identification of prospects and to cope with risks. This requires the enhancement of efficiency and effectiveness of information management to expand its readiness and value in decisionmaking. In spite of its significance, studies in information quality management (IQM), particularly those that investigate issues and challenges, are scarce. This paper, hence, attempts to fill this gap by taking into account both the theoretical and pragmatic approaches in viewing issues and challenges in IQM. In addressing the limited studies in IQM, the paper proposes possible areas of further inquiry for future research. It also seeks to provide a better insight into issues and challenges facing IQM as the study's practical impact.
\end{abstract}

Keywords: Information quality; Information quality management; Information system; Information management; Information power.

\section{Introduction}

As information is substantially instrumental in determining the survival of an organization, it is deemed as a key resource in business [1-2]. Considering its significance and extensive influence on the day-to-day functions to the strategic planning of the organization, it is imperative that information is given a special attention [3]. Although organizations acknowledge its importance and attempt to employ information sensibly, they encounter challenges to determine and prioritize quality information [4-5].

Essentially, the issue of information quality could only be addressed through IQM [5-7] because according to [8], quality is difficult to achieve without a form of management to ensure the product (information) is of superior quality. However, most organizations do not give priority to IQM [4]. In order for IQM strategies to work in generating the best outcome, it has to be wellformulated, namely to boost decision-making functions [9] as well as delivery of service [10].

Information quality is closely associated with information that meets users' needs [1]. This can only be obtained by implementing IQM. IQM practices should always be monitored and continuously enhanced to minimize risks and pitfalls which could endanger organizations. Paradoxically, studies on IQM are scarce [1113], especially on issues and challenges encountered in its implementation. These issues and challenges should be viewed from the information management perspective in order to device suitable and appropriate strategies to manage the quality of information. However, most organizations are yet to embark on IQM initiatives, while some organizations execute them without utilizing any strategy nor guide [4].

All the departments in an organization need quality information to make decisions, and even more so for the human resource department. Human resource personnel at all levels are the most critical resource for organizations to remain relevant and sustainable in the business environment [14-15]. Hence, the motivation of this study is to identify the issues and challenges in managing the quality of human resource information-handled either manually or electronically-in Malaysian public organizations. This is achieved by considering past studies in the area of information quality management as well as the thoughts of seasoned specialists who have managed public organizations' information.

\section{Information Quality and its Management}

Information quality is among the prevalent topics deliberated and explored by scholars, especially concerning issues that primarily deals with information systems management and information management perspectives [16].

The establishment of total quality management (TQM) concept in the 1980s has led to an increasing recognition towards quality of information, which saw information being perceived as a physical product and service [17]. The relevance of TQM is evident, namely as a notion that guides the entire practices and events carried out by the organizations in order to fulfill clients' requirements and achieve their goals using effective and economical approaches [18]. As a result, research put forward many models that fundamentally treat information as goods.

With the aim of meeting organizational as well as individual goals, information quality is constantly aligned to the requirements and anticipations of its consumers, including staff and clients [1]. In [1] further noted that information is perceived as a tangible outcome generated from knowledge inquiry in carrying out activities and not just a merchandise or a set of records.

If the information is considered to be valuable to users, particularly in terms of expediting decision-making, then it is perceived as possessing the essential quality. Information which is deficient in quality, however, poses complications to its users as well as organizations, even if it is widely accessible [19-20]. Although scholars listed several dimensions of information quality, in [5] 
found that the accuracy and completeness of information have a direct impact on the effectiveness of decision-making in producing quality results.

Nevertheless, studies that observe issues and challenges of IQM have not been done extensively in Malaysia, in line with $[2,21]$ claim that information and its management are not given priority in developing countries as compared to that of developed countries. Nonetheless, studies on issues and challenges in IQM are crucial as it can serve as the basis for developing IQM implementation strategies efficiently and effectively, particularly for public organizations in Malaysia.

\section{Methodology}

To examine the emerging issues and challenges in IQM, a rigorous literature review, together with semi-structured interviews were carried out. The research question, "What are the issues and challenges facing the public sector in IQM?" was formulated and addressed using the first method. Keyword threads namely "information quality", "data quality", "information quality management", "data quality management", "issues", "challenges" and "public sector" were applied in conducting search in numerous online databases. Since the study of IQM within the context of public service is inadequate, the study also considered more wideranging contexts such as quality management, information management, and IQM in general or in other contexts. Meanwhile, the latter method was applied to seek responses from three industry experts, namely in the area of human resource information management within the public-sector domain. The features of information management that the experts correspond to covers the comprehensive spheres of strategic, tactical, and operational domains. Table 1 indicates the professional background of the selected experts.

Table 1: Experts' Background

\begin{tabular}{|c|c|c|c|}
\hline Expert ID & Roles in organization & Work experience (years) & Work experience in the related field (years) \\
\hline E-01-S & $\begin{array}{c}\text { Information management expert } \\
\text { (Top management/Strategic level) }\end{array}$ & 28 & 19 \\
\hline E-02-T & $\begin{array}{c}\text { Information management expert (Senior manage- } \\
\text { ment/Tactical level) }\end{array}$ & 14 & 17 \\
\hline E-03-O & $\begin{array}{c}\text { Information management expert (Operational } \\
\text { level) }\end{array}$ & 22 & 17 \\
\hline
\end{tabular}

The following questions were utilized in the interviews to seek feedbacks pertaining to public institutions' IQM practices in Malaysia: (1) the current scenario in managing information quality; (2) the issues and challenges of IQM; and (3) the effects of information quality on the organization. The interviews, which spanned 50 to 60 minutes, were recorded, transcribed and analyzed. The data analysis consisted of the steps proposed by [22], namely familiarization, transcription, organization and coding, building of description, and report writing.

\section{Results and Discussion}

The results derived from the document analysis and interview sessions are summarized in Table 2.

Table 2: Issues and Challenges in IQM

\begin{tabular}{|c|c|c|}
\hline \multirow{2}{*}{ Issues and Challenges in IQM } & \multicolumn{2}{|c|}{ Source } \\
\hline & Literature & Interview \\
\hline Lack of references on factors influencing information quality & {$[12-13,23]$} & $\sqrt{ }$ \\
\hline Lack of references on the effects of information quality & {$[5,24-25]$} & $\sqrt{ }$ \\
\hline Lack of references on IQM model & [13] & $\sqrt{ }$ \\
\hline Lack of top management's commitment & - & $\sqrt{ }$ \\
\hline No policy on information quality and its management & - & $\sqrt{ }$ \\
\hline Lack of competencies and experiences & - & $\sqrt{ }$ \\
\hline Challenges in information system & [26-27] & $\sqrt{ }$ \\
\hline
\end{tabular}

The following sections provide further clarification on the issues and challenges in IQM as highlighted in Table 2, together with a number of proposed solutions.

\subsection{Lack of References on Factors Influencing Infor- mation Quality}

Although information is critical to an organization, studies on factors influencing information quality and its management are still limited [11-13, 23]. As a result, most organizations cannot effectively implement IQM [4] because they are unable to establish the right strategies.

Several previous studies such as by [11-13, 28-30] evaluated factors influencing information quality in the information system, while in $[18,31]$ analyzed factors that influence information quality in document. It is vital to emphasize here that information needs to be viewed universally [1] regardless of its type and medium. Parallel to this opinion, the laws on information quality such as Information Quality Act (also known as Data Quality Act) which is implemented in the United State of America, Sarbanes-Oxley and Basil II treated information as a universal subject.

All the experts in this study concurred that the quality of information needs to be viewed in total, regardless of whether the me- dium used is manual or electronic, as found in the practices of Malaysian public organizations in managing information. They also agreed that factors influencing the quality of information need to be identified. This is because they observed the lack of references pertaining to factors influencing information quality in the context of public organizations, especially in Malaysia. Malaysian public organizations have their own unique characteristics, which lead the factors to be different from other contexts (Expert E-01S). To address this, specific studies should be carried out to draw better strategies to be used as the basis for developing effective IQM practices. The identified factors need to encompass four aspects: organization, process, technology, and individuals, in forming a more comprehensive IQM (Expert E-01-S and E-02-T). It should also takes into consideration all the individual factors or parties involved in information management, covering the top management, middle management, employee, information supplier, and the information users (Expert E-01-S, E-02-T and E-03-O). Among the factors the experts deemed as influencing information quality include top management commitment, policy, process management throughout the information life cycle, employee morals and ethics, employee competencies, employee empowerment, training and education, information users focus, continuous improvement, quality of information system, information product 
design, benchmarking, information supplier management, teamwork and reward. Expert E-01-S and E-02-T went further to suggest that each of these factors need to be examined in detail, namely in terms of their relationship with information quality to allow the factors to be sorted according to priority.

\subsection{Lack of References on the Effects of Information Quality}

According to [5, 24-25] studies that analyze the effects of information quality in the context of the organizations are scarce, whereas such studies are particularly important in raising awareness about the importance of information quality to organizations and their employees. Hence, in [24] concluded that past studies on the impact of information quality were mostly focused on the success of technology adoption, while the effects on other aspects received less focused.

All the experts argued that references on the effects of information quality on the organization are insufficient. In fact, Expert E-02-T remarked that of now, he has yet to find a study on the impact of quality of information, especially within the context of public organizations in Malaysia. Such studies are important to raise awareness to top management and all the parties involved in managing organizational information (Expert E-01-S and E-02-T). Top management should understand their role in the implementation of information quality management. Similarly, employees need to ensure that the information they handle achieves the specified quality (Expert E-03-O). Given that the quality of information is seen to have a critical impact on organizational decision-making and performance, Expert E-01-S suggested that studies in these contexts should be implemented to provide an understanding of the organization as well as to empower the quality of information management practices in organizations.

\subsection{Lack of references on IQM model}

In [13] stressed that there are not many models or frameworks established for IQM. In fact, in [30] observed that existing models are not comprehensive enough as they do not incorporate individual, organizational, and technology factors. Due to the lack of references to characterize the IQM model, in [4] found that most organizations do not implement IQM efficiently and effectively. All the experts also concurred that at the moment, public organizations in Malaysia have no specific model of IQM. They further emphasized that the establishment of the model is important as it can guide public organizations to effectively manage their information. IQM strategies and activities can be established based on the model (Expert E-01-S) as well as by evaluating the current management practices to achieve improvements (Expert E-02-T). IQM model should be developed by taking into account the key factors affecting the quality of information (Expert E-01-S and E02-T) as well as the impact of information quality, especially on decision-making and organizational performance (Expert E-01-S and E -03-O). Expert E-01-S and E-02-T claimed that this model is comprehensive as it contains inputs (factors that influence the quality of information), the main subject/process (information quality/IQM), and output/outcome (effects of information quality). The relationship between each factor and the quality of information needs to be identified and the strength of the relationship should be assessed. This would provide a clear picture of the factors that need to be given priority (Expert E-01-S).

However, before further studies on the development of this model are implemented, studies should focus on identifying the level of IQM practices in public organizations and their implementation first. This would reveal the current scenario of IQM in an organization as well as indicate areas that need improvements (Expert E01-S).

\subsection{Lack of Top Management's Commitment}

The top management needs to understand the importance of quality information products owned by their organization. All parties, especially the top management are responsible for information quality. To achieve continuous quality improvement, top management should be directly involved in planning and implementing quality management programs and activities [8]. In other words, the success of quality management in the organization is dependent to the top management's commitment [32]. Top management cannot release its responsibilities to others and it needs to demonstrate leadership to achieve the expected product quality. Commitment and active involvement of top management is an important basis for ensuring the success of the overall quality management in to producing high quality products [32-33] including information products $[12,28]$.

Most of the top management members in public organizations understand the importance of information quality to their organizations (Expert E-01-S and E-02-T) and acknowledge their roles and responsibilities (Expert E-01-S) to this end. However, due to the task loads and time constraints they face, the roles and responsibilities are often handed over to other officers (Expert E-02-T and E-03-O). This situation can lead to grave consequences to IQM implementation in the organization. Top management should give a solid commitment to every program and activity related to IQM. Simultaneously, employees will give their best commitment in managing information, parallel with the directions and involvement of top management (Expert E-03-O). In addition, top management needs to clearly identify the goals of information quality in order to create a uniformed understanding of the same by the employees.

\subsection{No Policy on Information Quality and its Manage- ment}

In general, the policy on quality enforced within the organization is a requirement to successfully implement quality management as well as to ensure the quality of the product produced [32]. Accordingly, in $[12,26]$ concluded that the policy is a factor that affects the quality of information.

Unfortunately, up until now, public organizations in Malaysia have yet to have any specific policy for information quality or its management (Expert E-01-S, E-02-T, and E-03-O). Policy is critical because the principles and the set of strategies contained can guide the actions of an organization and its employees to achieve the established quality standards (Expert E-01-S, and E-02-T). In this regard, organizations need to devise and establish their own information quality policy and implement them wholly and effectively. All employees need to be informed about the content of the policy (Expert E-03-O). According to Expert E-02-T and E-03-O, the policy should be explained clearly in order to be understood by all the employees in the organization. The policy also needs to be in tandem with the management processes involved in dealing with information (Expert E-01-S and E-03-O). Moreover, the organization has to provide a continuous monitoring of the implementation of the policy as well as ensure that the quality of information is attainable.

\subsection{Lack of Competencies and Experiences}

One of the key principles of TQM is that all individuals in the organization need to be involved in the process of quality improvement, decision-making, problem solving, and organizational performance improvement [34] as quality is the responsibility of every individual in the organization. Employees are an essential element in quality management because they are individuals who are involved in the development and management process of the organization's product. Employees need to detect and repair defects of products throughout the production process. Accordingly, 
in [11] and [28] established that competency and experience of the employees were factors that influence information quality.

Consistent with this opinion, Expert E-01-S and E-03-O ascertained that most of the problems involving information quality are caused by the lack of competent and experienced workers. In fact, it is undeniable that most information defects are attributable to mistakes made by employees (Expert E-01-S and E-02-T). E-03-O further emphasized that many employees, especially in the tactical and strategic levels do not have enough experience and skills in managing information because they are not knowledgeable or trained in information management. In fact, most of them come from backgrounds (academic and previous job scope) that are different from the field of information management (E-03-O). According to E-03-O, there should be special schemes/positions (at all levels of operation, tactical and strategic) to manage organizational information. Such positions should not be filled by officers from other schemes to ensure that there is no inconsistency in IQM.

Expert E-01-S added that organizations should always provide training on information quality and its management to enhance employees' knowledge and competencies as well as to create awareness among them. Trained workers can perform tasks optimally to achieve organizational goals (Expert E-01-S and E-02-T). The organization also needs to implement employee empowerment initiative by giving their employee the power to solve their own problems and make decisions related to their work (Expert E01-S). In order to improve the motivation and morale of employees to always produce quality work outcome, organizations need to have a good rewarding system to give recognition to employees who perform.

\subsection{Challenges in Information System}

According to [28], technology factors that include support of computing infrastructure resources, system adoption, system integration and database synchronization, capability constraint of system and user interface, data cleansing and use of data quality tools, data quality monitor/control and data verification, and automated data capture affect the quality of information. Meanwhile, in [11] found that the nature of information system is another factor that affects the quality of information. Accordingly, in [35-36] observed that the quality of the information system affects the quality of information within the system. This shows that organizations are faced with challenges arising from the use of information systems. However, it is undeniable that the use of information systems can have a positive impact on the management of information from various aspects.

All the experts argued that in the era of modern technology, the use of information systems is a must. In this regard, all public organizations in Malaysia have been instructed to utilize the Human Resource Management Information System (HRMIS) to manage the human resource information of their respective organizations. Although HRMIS a centralized system, organizations face challenges to implement it, especially in terms of the application of technology (Expert E-02-T and E-03-O). Among the problems faced by HRMIS users include failures in the system's function, slow response time, not user-friendly, generation of unreliable data, and difficulty to use [26-27].

\section{Conclusion}

Information is crucial to achieve the organization's goal and objectives, in addition to making the organization emerge as a practitioner of democracy by demonstrating transparency, accountability, and protecting individual rights. Problems with information quality should be addressed explicitly, especially when dealing with the phenomenon of information overflow. Organizations should address the issues and challenges faced in managing information quality so as to enable information to be used as a stra- tegic source for survival and resilience as well as a tool for them to remain competitive despite of their liability. It is timely for organizations to have an information quality agenda via an information-transformation approach to serve as a reliable source to support any action and decision.

This study offers insights into the issues and challenges in the IQM field with the aim of justifying efforts to address them. To this end, seven issues and challenges in the IQM field have been identified through document analysis and expert review methods namely (1) lack of references on factors influencing information quality, (2) lack of references on effects of information quality, (3) lack of references on IQM model, (4) lack of top management's commitment, (5) no policy on information quality and its management, (6) lack of competencies and experiences, and (7) challenges in information system. This paper stands as a pioneering study that would pave the way for future research in the field of IQM, particularly in relation to organizations in Malaysia's public sector, owing to the scarcity in the scholarly research in the field. In terms of practical contribution, the insights established in this study can guide organizations to better understand the issues and challenges in sustaining IQM.

Based on identified issues, this study strongly suggests that an IQM model for public sector needs to be constructed. The development of this model should be grounded on key factors that influence information quality and their effects. The factors should cover four aspects/dimensions namely (1) organization, (2) process, (3) individual and (4) technology to form a more comprehensive model. For the individual dimension, considerations should be given to all parties involved in managing the organizational information such as the top management, middle management, employees, information suppliers, and information users. The effects of information quality on decision-making and organizational performance should also be taken into account. The data collection used in analyzing and verifying this model need to cover all types of services, namely federal public services, state public services, federal statutory bodies, state statutory bodies, and local authorities. The model is expected to be applied as a guide to empower IQM practices and enhance service delivery and in turn boost the competitiveness of the organization.

\section{Acknowledgement}

The study is financially supported by Research Grant GUP-2017046, Universiti Kebangsaan Malaysia and the Public Services Department of Malaysia.

\section{References}

[1] English LP, Information Quality Applied: Best Practices for Improving Business Information, Processes and Systems, Wiley Publishing, Indianapolis, (2009).

[2] Yusof ZM, Pengurusan Rekod dan Maklumat: Isu dan Cabaran, Penerbit Universiti Kebangsaan Malaysia, Bangi, (2015).

[3] Al-Hakim L, "Surgical disruption: information quality perspective," International Journal of Information Quality, Vol. 2, No. 2, (2008), pp. 192-204

[4] Baškarada S, Information Quality Management Capability Maturity Model, Vieweg+Teubner, Wiesbaden, Germany, (2009).

[5] Ge M, Information quality assessment and effects on inventory decision-making, Ph.D Thesis, Dublin City University. (2009).

[6] Price R, Shanks G, "A semiotic information quality framework: development and comparative analysis," Journal of Information Technology, Vol. 20, No. 2, (2005), pp. 88-102.

[7] Kusumah RTP, Suhardi, "Designing Information Governance in Statistical Organization," Proceedings of Information Technology System and Innovation (ICITSI), (2014), pp. 201-205.

[8] Oakland JS, Total quality management, Butterworth-Heinemann, (1993).

[9] Mukred M, Yusuf Z.M, "The DeLone-McLean Information System Success Model for Electronic Records Management System Adoption in Higher Professional Education Institutions of Yemen," In- 
ternational Conference of Reliable Information and Communication Technology IRICT 2017: Recent Trends in Information and Communication Technology, (2017), pp. 812-823.

[10] Yusof ZM, Ismail MB, Ahmad K, Yusof MM, "Knowledge sharing in the public sector in Malaysia: A proposed holistic model," Information Development, Vol. 28, No. 1, (2012), pp. 43-54.

[11] Xu H, Critical Success Factors for Accounting Information System. Data Quality, P.hD Thesis, University of Southern Queensland, Australia, (2003).

[12] $\mathrm{Xu} \mathrm{H}$, "What are the most important factors for accounting information quality and their impact on AIS data quality outcomes?" ACM J. Data Inf. Qual. 5, Article 14, (2015).

[13] Baškarada S, Koronios A, "Critical Success Factor Framework for Information Quality Management," Information Systems Management, Vol. 31, No. 4, (2014), pp. 276-295.

[14] Public Service Department of Malaysia, HRMIS Transformation of the Malaysian Public Sector Human Resource Management of the 21st Century, Public Service Department of Malaysia, Cyberjaya, (2010).

[15] Othman N, Ahmad Z, Hamzah MIM, "Pengaruh Amalan Pengurusan Sumber Manusia (PSM) terhadap Hasil PSM di IPTS Bukan Bertaraf Universiti," Jurnal Pengurusan, Vol. 31, (2010), pp. 4353.

[16] Lee YW, Strong DM, Kahn BK, Wang RY, “AIMQ: a Methodology for Information Quality Assessment. Information \& Management," Vol. 40, No. 2, (2002), pp. 133-146.

[17] Shankaranarayan G, Ziad M, Richard YW, "Managing Data Quality in Dynamic Decision Environments: An Information Product Approach," Journal of Database Management, Vol. 14, No. 4, (2003).

[18] Levis M, Information Quality Training Requirements Analysis Guideline Demonstrated in a Healthcare Context, P.hD Thesis, Dublin City University, (2011)

[19] Rad SSE, Embong Z, "International Financial Reporting Standards and Financial Information Quality: Principles versus Rules-based Standards," Jurnal Pengurusan, Vol. 39, (2013), pp. 93-109.

[20] Shi C, Jugulum R, Joyce HI, Singh J, Granese B, Ramachandran R, Gray D, Heien $\mathrm{CH}$, Talburt JR, "Improving financial services data quality - a financial company practice," International Journal of Lean Six Sigma, Vol. 6, No. 2, (2015), pp. 98-110.

[21] Wamukoya JM, "Records and archives as a basis for good government: Implication and challenges for records managers and archivists in Africa," Records Management Journal, Vol. 10, No. 1, (2000), pp. 23-33.

[22] Yin RK, Qualitative Research from Start to Finish, The Guilford Press, New York, (2011).

[23] Tee SW, Bowen PL, Doyle P, Rohde FH, "Factors influencing organizations to improve data quality in their information systems," Accounting and Finance, Vol. 47, No. 2, (2007), pp. 335-355.

[24] Harrison DE, Understanding the Impact of Information Quality on Customer Relationship Management, P.hD Thesis, Kennesaw State University, (2016).

[25] Ali BJA, Omar WAW, Bakar R, "Accounting Information System (AIS) and Organizational Performance: Moderating Effect of Organizational Culture", International Journal of Economics, Commerce and Management United Kingdom, Vol. 4, No. 4, (2016), pp. $138-158$.

[26] Jabatan Perkhidmatan Awam, Unit Pemodenan Tadbiran dan Perancangan Pengurusan Malaysia, "Kajian keberkesanan pelaksanan SMPC dan SMPT dalam pengurusan sumber manusia sektor awam", (2011) 1-33. http://www.eghrmis.gov.my/docs/pdf/buletin/2011/laporan-brc.pdf.

[27] Ibrahim H, The determinants of end-user satisfaction with HRMIS and its influence on individual performance in government agencies in Malaysia, P.hD Thesis, University Sains Malaysia, (2016)

[28] Lin CS, Building a Framework for Improving Data Quality in Engineering Asset Management, P.hD Thesis, University of South Australia, (2008).

[29] Lubis MA, Pengaruh Mekanisma Tadbir Urus Korporat Terhadap Kualiti Data Industri Perkilangan di Sumatera Utara, Indonesia P.hD Thesis, Universiti Utara Malaysia, (2012).

[30] Mohammed SA, Yusof MM, "Towards an evaluation framework for information quality management (IQM) practices for health information systems - evaluation criteria for effective IQM practices," Journal of Evaluation in Clinical Practice, Vol. 19, No. 2, (2013) pp. 379-87.
[31] Manan LMA, Iskandar TM, "Kualiti Pelaporan Maklumat Syarikatsyarikat di Bursa Saham Kuala Lumpur,' Jurnal Pengurusan, Vol. 22, (2003), pp. 27-45.

[32] Oakland J, "Leadership and policy deployment: the backbone of TQM," Total Quality Management and Business Excellence, Vol. 22, No. 5, (2011), pp. 517-534.

[33] Aquilani B, Silvestri C, Ruggieri A, Gatti C, "A systematic literature review on total quality management critical success factors and the identification of new avenues of research," The TQM Journal, Vol. 29, No. 1, (2017), pp. 184-213.

[34] Talib F, Rahman Z, "Critical success factors of TQM in service organizations: a proposed model", Services Marketing Quarterly, Vol 31, No. 3, (2010), pp. 363-380.

[35] Gorla N, Somers TM, Wong B, "Organizational Impact of System Quality, Information Quality, and Service Quality," Journal of Strategic Information Systems, Vol. 19, No. 3, (2010), pp. 207-228.

[36] Al-Mamary YH, Shamsuddin A, Aziati N, "The Impact of Management Information Systems adoption in Managerial Decision Making: A Review", The International Scientific Journal of Management Information Systems, Vol. 8, No. 4, (2013), pp. 10-17. 